\title{
PERSEPSI MASYARAKAT KOTA BOGOR TERHADAP TAYANGAN TALK SHOW PAGI PAGI PASTI HAPPY DI TRANS TV
}

\author{
Yuyun Anggraini ${ }^{1}$, Rani Chandra Oktaviani ${ }^{2}$, Alvikha Adrian ${ }^{3}$ \\ London School of Public Relations Communication \& Business Institute \\ Email: 18220130319@1spr.edu
}

\begin{abstract}
ABSTRAK
Tayangan Televisi di Indonesia memiliki program acara yang cukup beragam. Beberapa tayangan cukup mengedukasi sedangkan sebagian lagi dinilai kontroversional disebabkan oleh beberapa faktor. Salah satu tayangan yang dinilai kontroversional adalah tayangan talkshow Pagi Pagi Pasti Happy yang tayang di Trans TV karena sudah mendapatkan beberapa kali teguran dari KPI. Namun tak sedikit masyarakat yang memandang Pagi Pagi Pasti Happy sebagai tayangan yang baik dan menghibur. Di balik kontroversi Pagi Pagi Pasti Happy, tayangan tersebut masih banyak mendapatkan dukungan masyarakat. Penelitian ini bertujuan untuk mendeskripsikan persepsi masyarakat di Kota Bogor terhadap tayangan Pagi Pagi Pasti Happy di Trans TV serta untuk mengetahui bagaimana persepsi positif dan negatif masyarakat di Kota Bogor terhadap tayangan Pagi Pagi Pasti Happy di Trans TV. Dengan teori persepsi Joseph A. DeVito menggunakan metode deskriptif kualitatif serta analisis interaktif, ditemukan hasil penelitian persepsi masyarakat yang cukup beragam. Masyarakat dari kelas sosial menengah hingga menengah kebawah merasa terhibur dengan tayagan Pagi Pagi Pasti Happy. Namun, masyarakat yang cenderung mendapatkan pendidikan yang cukup serta berasal dari kelas ekonomi menengah keatas menilai bahwa Pagi Pagi Pasti Happy memang tayangan yang kontroversional. Fenomena ini memperlihatkan bahwa masyarakat masih menggemari tayangan yang bersifat kontroversional serta menyalahi kode etik penyiaran. Implikasi penelitian ini adalah diperlukannya kesadaran masyarakat untuk menonton tayangan baik.
\end{abstract}

Kata Kunci: Tayangan televisi, analisis interaktif, kontroversional

\section{BOGOR CITY PUBLIC PERCEPTION OF PAGI PAGI PASTI HAPPY TALK SHOW ON TRANS TV}

\begin{abstract}
Television shows in Indonesia have a variety of programs. Some shows are enough to educate while some are approved by controversy caused by several factors. One of the shows that contain controversy is talk show programs named Pagi Pagi Pasti Happy on Trans TV because it had received three times admonitions from KPI. But Pagi Pagi Pasti Happy is nice and entertaining television programs for some people. Behind the controversy, Pagi Pagi Pasti Happy still received a lot of public support. This study aims to describe Bogor city public perception about program Pagi Pagi Pasti Happy in Trans TV and to find out the positive and negative perceptions of people in Bogor city about Pagi Pasti Happy talk show in Trans TV. With Joseph A. DeVito's perception theory, using qualitative descriptive methods and interactive analysis, it was found that the research results on people's perceptions were quite diverse. People from middle to lower social classes are entertained by the Pagi Pagi Pasti Happy. However, people who have sufficient education also from middle to upper economic classes mark Pagi Pagi Pasti Happy as a controversial show. This phenomenon shows us if society still enjoys impressions that contains controversy and violates the broadcasting code of ethics. The implications of this research are needed, public awareness to watch good shows.
\end{abstract}

Keywords: Television shows, interactive analysis, controversial 
Korespondensi: Yuyun Anggraini. London School of Public Relations Communication \& Business Institute. Jl. K.H. Mas Mansyur, Kav 35, Jakarta Pusat, Indonesia, 10220. (+62)85245700637.18220130319@1spr.edu

\section{PENDAHULUAN}

Media massa merupakan komponen yang tak bisa dilepaskan oleh manusia. Pasalnya, berbagai informasi berlalu lalang melalui media massa. Media massa berperan penting dalam distribusi informasi kepada khalayak. Menurut McQuail (2011 p.95), media massa memberikan pengetahuan serta gambaran umum tentang dunia luar. Efek hipotesis dari kekuatan media massa dinilai menarik dan mengarahkan perhatian publik, mempersuasi opini dan keyakinan, mempengaruhi perilaku, memberikan definisi realitas, memberikan status pengesahan dan memberikan informasi dengan cepat dan luas. Maka dari itu media massa dapat disimpulkan sebagai medium yang memepengaruhi cara berfikir khalayak.

Menurut Straubhaar, LaRose \& Davenport dalam bukunya yang berjudul Media Now, Media massa terus mengalami perkembangan sehingga terbagi menjadi empat, yaitu Print Media, Radio, Televisi dan Internet (Straubhaar, LaRose \& Davenport, 2012 p.58). Di Indonesia, media utama bagi masyarakat adalah televisi. Dikutip dari Nielsen.com, survey yang dilakukan oleh lembaga Nielsen Indonesia seputar Consumer Media View (2017) menunjukkan bahwa penetrasi televisi mencapai 96 (persen). Di urutan kedua media luar ruang dengan penetasi 53 (persen), internet (44 persen), dan di posisi ketiga radio (37 persen). Hal ini dipengaruhi oleh kemampuan televisi yang dapat menyampaikan informasi secara audio visual. Kemampuan tersebut mempermudah khalayak untuk mendapatkan informasi secara cepat.

Acara televisi yang paling digemari penonton menurut survei AC Nielsen dalam Panuju (2017) yaitu infotaiment. Itu sebabnya mengapa semua stasiun televisi memiliki program ini, program yang menggambarkan human interest. Selain program acara infotaiment, menurut Panuju (2017 p.46) disebutkan bahwa salah satu yang ratingnya tinggi apabila menyiarkan konflik disertai caci maki.

Tidak hanya infotaiment, talk Show juga kerap membahas kehidupan public figure secara interaktif. Walaupun bersifat menghibur, beberapa acara televisi talk show sering kali mengenyampingkan masalah etika dan moral. Yuliandre Darwis dari KPI mengatakan bahwa saat ini konten acara lebih banyak diciptakan untuk menghibur semata, minim konteks edukasi. Padahal, idealnya lembaga penyiaran setidaknya bisa "menyisipkan nilai-nilai positif" untuk masyarakat. Frekuensi yang dipinjam oleh televisitelevisi swasta ini adalah milik publik (Aurelia, 2018).

Salah satu acara talk show yang dinilai paling kontroversial adalah Pagi Pagi Pasti Happy. Pasalnya, acara ini sudah mendapatkan beberapa kali teguran oleh KPI. Acara ini dibawakan oleh Uya Kuya, Billy Syahputra, serta Iis Dahlia yang mengulas berbagai permasalahan pribadi artis tanah air yang dicampur dengan komedi. Terhitung sejak November 2017 hingga Oktober 2019, 
tayangan Pagi Pagi Pasti Happy sudah mendapatkan 6 kali terguran, 2 kali peringatan serta 1 kali penghentian tayang sementara oleh KPI.

Namun, teguran KPI tidak berpengaruh terhadap share program talk show unggulan Trans TV ini. Dikutip dari cnnindonesia.com, La Ode menyebutkan bawah share acara Pagi Pagi Pasti Happy mencapai 6.5 \% (Juniman, 2017). Keunikan lain yang dibawakan acara tersebut adalah terdapat segmen tanya jawab dengan admin akun Lambe Turah. Lambe turah yang dikenal dengan akun gosip ternama di Indonesia, turut meramaikan acara Pagi Pagi Pasti Happy. Talk show di Pagi Pagi Pasti Happy terasa lebih menegangkan. Hal ini dipengaruhi oleh host yang membawa suasana lebih meriah, ramai, serta tak jarang mengupas tuntas permasalahan narasumber. Tak jarang Pagi Pagi Pasti Happy memanggil kedua belah pihak yang bertengkar, di waktu yang berbeda. Sehingga acara tersebut tindak hanya melihat masalah dari satu sisi (Rosana, Wawancara pra-riset, 18 Oktober 2018).

Target audience tayangan Pagi Pagi Pasti Happy berada di kelas ekonomi menengah hingga menengah kebawah. Hal ini tercermin dari pernyataan La Ode, selaku Produser tayangan Pagi Pagi Pasti Happy bahwa karakter penonton Indonesia umumnya tidak suka dengan tayangan yang berat. Penonton lebih memilih acara yang cenderung santai sebagai media hiburan bagi diri sendiri. Tayangan yang bisa ditonton tanpa harus lelah berpikir (Nurfikria \& Tawulo, 2018 p. 55).

Target audience dari kelas menengah hingga menengah kebawah serta jam tayang yang bersamaan dengan jam kerja, memberikan peluang tayangan Pagi Pagi Pasti Happy ditonton oleh pengangguran. Kota Bogor, yang berada di pinggiran ibu kota masih memiliki persentasi pengangguran yang tinggi. Dikutip dari Anasthasya (2018) dalam Radarbogor.id, kepala Badan Pusat Statistik Kota Bogor menyatakan bahwa, data angka pengangguran di Kota Bogor juga masih cukup tinggi di angka 9,57 persen atau dari 100 orang usia kerja, 9-10 orang masih menganggur. Hal ini mempengaruhi angka kemiskinan Kota Bogor. Data 2017 angka kemiskinan Kota Bogor berada di angka 7,11 persen. Dalam situs resmi Badan Statistik Kabupaten Tangerang dalam profil kemiskinan No. 05/01/36/Th.XII, 2 Januari 2018, persentasi kemiskinan di DKI Jakarta pada tahun 2017 tercatat sebesar 3,78\%, sedangkan persentasi kemiskinan di Tangerang tercatat 5,59\%.

Menurut data karakteristik audiens di kota Bogor, masyarakat di kota Bogor sesuai dengan kriteria audience tayangan Pagi Pagi Pasti Happy. Selain target audience yang berasal dari kelas menengah hingga menengah kebawah, Pagi Pagi Pasti Happy selalu mengundang kontroversi. Mengingat acara yang kontroversional dan memiliki share yang cukup tinggi, tertarik untuk dilakukan penelitian persepsi masyarakat di Kota Bogor terhadap tayangan Pagi Pagi Pasti Happy.

\section{METODE PENELITIAN}

Dalam penulisan ini, metode penelitian yang digunakan adalah metode deskriptif dengan jenis data kualitatif. Metode ini digunakan untuk mendeskripsikan fenomena yang sedang diteliti. Menurut Rahmat (2009), penelitian deskriptif 
hanya memaparkan situasi atau peristiwa, tidak mencari dan menjelaskan hubungan, tidak menguji hipotesis atau membuat prediksi (Asngad, 2016, p.29). Data primer didapatkan melalui wawancara mendalam dengan informan. Informan primer dalam penelitian ini yaitu penonton $\mathrm{P} 3 \mathrm{H}$ (Ibu Rumah Tangga), serta informan tambahan meliputi praktisi presenter televisi, teori dan penelitian sebelumnya. Penelitian menggunakan analisis interaktif Miles and Hubberman serta memiliki fokus penelitian sebagai berikut:

Tabel 1. Fokus Penelitian

\begin{tabular}{|c|c|c|}
\hline $\begin{array}{c}\text { Fokus } \\
\text { Penelitian }\end{array}$ & Elemen & Evidensi \\
\hline \multirow{17}{*}{ Persepsi } & \multirow[t]{2}{*}{$\begin{array}{c}\text { Stimulasi } \\
\text { (Stimulation) }\end{array}$} & $\begin{array}{l}\text { Seleksi Perhatian } \\
\text { (Selective } \\
\text { Attention) }\end{array}$ \\
\hline & & $\begin{array}{l}\text { Seleksi Informasi } \\
\text { (Selective } \\
\text { Exposure) }\end{array}$ \\
\hline & \multirow{3}{*}{$\begin{array}{c}\text { Organisasi } \\
\text { (Organization) }\end{array}$} & Aturan (Rules) \\
\hline & & Skema (Schemata) \\
\hline & & Naskah (Script) \\
\hline & \multirow{8}{*}{$\begin{array}{c}\text { Interpretasi - } \\
\text { Evaluasi } \\
\text { (Interpretation - } \\
\text { Evaluation) }\end{array}$} & $\begin{array}{l}\text { Pengalaman } \\
\text { (Experience) }\end{array}$ \\
\hline & & Kebutuhan (Needs) \\
\hline & & Keinginan (Wants) \\
\hline & & Nilai (Values) \\
\hline & & $\begin{array}{c}\text { Keadaan Fisik dan } \\
\text { Emosional } \\
\text { (Physical and } \\
\text { Emotional State) }\end{array}$ \\
\hline & & $\begin{array}{c}\text { Ekspetasi } \\
\text { (Expectations) }\end{array}$ \\
\hline & & $\begin{array}{l}\text { Jenis Kelamin } \\
\text { (Gender) }\end{array}$ \\
\hline & & Keyakinan (Beliefs) \\
\hline & \multirow[t]{2}{*}{$\begin{array}{l}\text { Memori } \\
\text { (Memory) }\end{array}$} & $\begin{array}{l}\text { Konsisten } \\
\text { (Consistent) }\end{array}$ \\
\hline & & $\begin{array}{c}\text { Resisten } \\
\text { (Resistance) }\end{array}$ \\
\hline & \multirow{2}{*}{$\begin{array}{c}\text { Mengingat } \\
\text { Kembali }(R e- \\
\text { call })\end{array}$} & $\begin{array}{c}\text { Reproduksi } \\
\text { (Reproduction) }\end{array}$ \\
\hline & & $\begin{array}{c}\text { Rekonstruksi } \\
\text { (Reconstruction) }\end{array}$ \\
\hline
\end{tabular}

Data Olahan Peneliti, 2019.

Teori Persepsi

Penelitian dilakukan dengan metode dekriptif kualitatif untuk melihat secara detail persepsi masyarakat di kota Bogor terhadap tayangan Pagi
Pagi Pasti Happy. Penelitian mengacu pada penelitian terdahulu yaitu artikel jurnal penelitian milik Sri Yulianti yang berasal dari Universitas Mulawarman Samarinda Universitar Mulawarman Samarinda. Tujuan penelitian ini adalah untuk mengetahui persepsi masyarakat tentang Program Acara Reality Show "Catatan Si Olga" di Kelurahan Gunung Lingai Kecamatan Sungai Pinang Samarinda dengan metode penelitian deskriptif kualitatif. Didapatkan hasil penelitian berupa Acara Reality Show "Catatan Si Olga" memiliki nilai pesan moral yang ditujukkan dengan penayangan yang sifatnya mengajarkan kepada masyarakat/audiens untuk dapat saling membantu antar sesama manusia yang membutuhkan. Program acara ini telah mampu membuat persepsi yang "Cukup Baik" di masyarakat Kelurahan Gunung Lingai Kecamatan Sungai Pinang Samarinda (Yulianti, 2013 p.46).

Menurut Joseph A. Devito (2009) persepsi adalah serangkaian proses berkelanjutan yang saling terkait, saling mempengaruhi, bersifat kontinyu, campur baur dan tumpang tindih antara satu dengan yang lain. Terdapat lima tahapan dalam persepsi yaitu Stimulasi, Organisasi, Interpretasi-Evaluasi, Memori, serta Mengingat kembali (Re-call). Berikut merupakan penjelasan kelima tahap tersebut:

\section{Stimulasi (Stimulation)}

Stimulasi adalah tahap dimana individu menerima informasi atau stimuli melalui inderanya. Pada tahap ini terjadi seleksi sehingga ada stimulus yang diabaikan dan tidak diabaikan (Fairush, 2013, p.15). Namun, tidak seluruh rangsangan diterima oleh manusia, karena manusia memiliki selective 
perception yang terbagi menjadi selective attention dan selective exposure (DeVito, 2009, p.68). Dalam selective attention manusia lebih memperhatikan hal-hal yang akan memenuhi kebutuhan diri serta hal-hal yang menyenangkan. Sedangkan di dalam selective exposure manusia akan cenderung mencari informasi yang memperkuat keyakinan yang ada. Karena, hal tersebut berkontribusi untuk tujuan tertentu, ataupun sekedar memberikan rasa puas.

\section{Organisasi (Organization)}

Menurut DeVito, pada tahapan ini setiap individu akan mengelola setiap informasi yang masuk melalui alat indra mereka melalui beberapa cara baik itu melaluiperaturan (rules), skema (schemata), dan naskah (script) (Fairush, 2013, p.15).

Rules

Didalam rules, informasi yang masuk dipengaruhi oleh kedekatan (proximity). Berdasarkan proximity, manusia akan melihat orang-orang yang sering bersama. Atau pesan yang diucapkan kepada satu sama lain sebagai satu kesatuan milik bersama (DeVito, 2009, p.68-69). Selain itu, terdapat prinsip kesamaan (similiarity), dimana manusia mengelompokan hal-hal yang serupa menjadi sebuah kesatuan. Misalnya manusia mengelompokan orang-orang yang tinggal di apartement yang sama. Prinsip yang terakhir adalah perbedaan (contrast). Kontras dapat jelas terlihat ketika orang-orang tidak bisa bersatu karena perbedaan yang terlalu mencolok, sehingga sulit untuk ditempatkan dalam satu kesatuan.

Schemata
Cara lain dalam mengelola informasi atau materi adalah dengan membuat skema, yaitu kerangka yang dapat membantu dalam mengelola berbagai informasiyang diperoleh setiap saat. Skema membuat kita menghapus informasi positif ketika stereotype bersifat negatif, dan sebaliknya. Manusia membentuk skema melalui pengalaman pribadi, menonton televisi, membaca, maupun mendengar. Misalnya, anda memiliki skema yang menggambarkan atlet dari perguruan tinggi terlihat kuat, ambisius, lemah secara akademis serta egois (DeVito, 2009 p.69).

\section{- $\quad$ Script}

Mirip seperti skema, namun skrip merupakan sekumpulan informasi yang telah di tata dan lebih fokus terhadap aksi, peristiwa, maupun prosedur. Contohnya, manusia telah memiliki skrip bagaimana cara me-laundry pakaian.

3. Interpretasi - Evaluasi (Interpretation Evaluation)

Tahap ini merupakan tahap dimana individu melakukan penerjemahan atau penafsiranmakna dari informasi yang masuk melalui alat indra manusia. Penafsiran sebuahinformasi melibatkan beberapa aspek yaitu pengalaman masa lalu individu, nilaiyang dianut tiap individu, harapan individu dan lain sebagainya (Fairush, 2013, p.1516). Tahap tersebut sangat dipengaruhi oleh pengalaman (Experience), kebutuan (Needs), keinginan (Wants), nilai (Values), ekspetasi (Expectations), keadaan fisik dan emosional (Physical and emotional state), jenis kelamin (Gender), dan keyakinan mengenai bagaimana seharusnya suatu hal terjadi (Beliefs about the way things are or should be) (DeVito, 2009 p.70). 


\section{Memori (Memory)}

Memori merupakan tahap dimana manusia menyimpan informasi yang sudah ditafsirkan sebelumnya. Pengertian memori menurut Chaplin yaitu fungsi yang terlibat dalam proses mengenang masa lalu, keseluruhan pengalaman masa lalu yang diingat kembali, dan pengalaman masa lalu yang khas (Chaplin, 2011 p.295). Menurut Aronson, Wilson, \& Akert (2002) Memori yang konsisten dengan skema penerima akan memperkuat skema sehingga membuatnya lebih resistan terhadap perubahan. Memori, setelah melalui tahap Interpretation-Evaluation, persepsi seseorang telah terbentuk dan kemudian disimpan ke dalam memori untuk suatu saat akan dimunculkan kembali ketika melihat atau mendengar sesuatu yang sesuai dengan persepsi yang telah terbentuk (Fairush, 2013, p.16).

\section{Mengingat Kembali (Recall)}

Recall adalah tahap dimana manusia memunculkan kembali persepsi individu yang tersimpan di dalam memori. Dalam proses ini apa yang telah didengar atau dilihat tidak direproduksi begitu saja, tetapi direkonstruksi kembali hal yang telah didengar atau dilihat tersebut kepada keseluruhan yang memiliki arti tergantung seberapa besar skema dan script yang dikonstruksi di dalam memori (DeVito, 2009 p.71).

Proses interpretasi persepsi dipengaruhi oleh beberapa faktor. David Krech dan Richard S. Crutchfield menyebutkan faktor perhatian lebih berpengaruh terhadap persepsi. Sedangkan menurut DeVito (1997) salah satu hal yang mempengaruhi persepsi adalah stereotip. Menurut Lippmann (1922 p.1-16), stereotip adalah gambar di kepala yang merupakan rekonstruksi dari keadaan lingkungan yang sebenarnya. Selanjutnya, ia berpendapat bahwa stereotip merupakan salah satu mekanisme penyederhana untuk mengendalikan lingkungan, karena keadaan lingkungan yang sebenarnya terlalu luas, terlalu majemuk, dan bergerak terlalu cepat untuk bisa dikenali dengan segera (Rosihan, 2012, p.50).

Selain stereotip, menurut DeVito (1997 p.77-84) beberapa faktor yang mempengaruhi persepsi, yaitu:

1. Teori Kepribadian Implisit (Implicit Personality Theory), adalah system aturan yang mengatakan kepada kita makna karateristik yang sesuai dengan makna karateristik yang lain

2. "Efek Halo" merupakan fungsi dan teori kepribadian implisit kita. Jika kita percaya bahwa seseorang memiliki sejumlah kualitas positif, kita akan menyimpulkan bahwa ia juga memiliki kualitas positif yang lain. "Efek Halo Terbalik" juga ada, yaitu jika kita tahu bahwa seseorang memiliki sejumlah kualitas negatif, maka kita akan cenderung menyimpulkan bahwa orang itu juga memiliki sejumlah kualitas negatif lainnya.

3. Ramalan yang terpenuhi dengan sendirinya (Self-Fulfilling Prophecy). Hal ini terjadi apabila kita membuat perkiraan atau merumuskan keyakinan yang menjadi kenyataan karena kita meramalkannya dan bertindak seakan-akan itu benar.

4. Aksentuasi perseptual (Perceptual Accentuation). Proses aksentuasi perceptual ini membuat kita melihat apa yang kita harapkan dan inginkan, seperti kita melihat orang yang kita sukai 
sebagai lebih tampan/cantik dan baik demikian juga sebaliknya.

5. Primasi Resensi (Primacy Recency). "Efek Primasi" merupakan efek awal yang mempengaruhi persepsi seseorang. Sedangkan "Efek Resensi" merupakan efek terakhir atau yang paling baru yang mempengaruhi persepsi seseorang.

6. Konsistensi (Consistency). Kita punya kecenderungan yang kuat untk menjaga keseimbangan atau konsistensi di antara persepsipersepsi kita. Konsistensi menggambarkan kebutuhan kita untuk memelihara keseimbangan di antara sikap-sikap kita.

7. Stereotip (Stereotyping). Jalan pintas yang sering digunakan dalam persepsi adalah stereotype. Stereotype adalah istilah dalam bidang percetakan yang mengacu pada suatu pelat yang mencetak citra (gambar atau tulisan) yang sama berulangulang.

\section{HASIL DAN PEMBAHASAN}

Berdasarkan hasil analisis penelitian, ditemukan persepsi masyarakat terkait dengan tayangan Pagi Pagi Pasti Happy. Terdapat persepsi positif tercermin dari respon narasumber ketika di wawancarai seputar konten dalam Pagi Pagi Pasti Happy. Narasumber menilai bahwa Pagi Pagi Pasti Happy tidak hanya menayangkan seputar konflik public figure, tetapi juga turut menyajikan konten yang berhubungan dengan human interest, keselamatan diri, serta penayangan video video viral yang dianggap menghibur. Namun, berkembang pula persepsi negatif di dalam masyarakat yang tercermin dari respon narasumber yaitu Pagi Pagi Pasti Happy dianggap mengabaikan nilai etika penyiaran. Selain itu bila ditinjau dari segi konten, Pagi Pagi Pasti Happy dianggap memiliki konten yang kurang mendidik serta lebih berfokus kepada fungsi menghibur.

Ditinjau dari tujuan penelitian terdapat dua aspek yang ingin di teliti. Yaitu untuk mendeskripsikan persepsi masyarakat di kota Bogor terhadap tayangan Pagi Pagi Pasti Happy di Trans TV serta untuk mengetahui persepsi positif dan negatif masyarakat di kota Bogor terhadap tayangan Pagi Pagi Pasti Happy. Berikut adalah deskripsi persepsi masyarakat di kota Bogor terhadap tayangan Pagi Pagi Pasti Happy ditinjau dari tahapan persepsi menurut DeVito:

\section{Stimulasi}

Pada tahap ini ditemukan bahwa narasumber menilai Pagi Pagi Pasti Happy merupakan program acara yang menyiarkan seputar konflik public figure, human interest hingga konten konten yang bertema soft news. Narasumber mengungkapkan bahwa konten yang disampaikan Pagi Pagi Pasti Happy dapat memenuhi kebutuhan pribadi mengenai informasi public figure. Hal ini dikarenakan tayangan tersebut kerap kali mengulas secara mendalam mengenai konflik public figure. Kesimpulan ini diambil dari pernyataan narasumber penonton Pagi Pagi Pasti Happy di Kota Bogor

"pernah, iya suka gitu. Acaranya tentang mengedukasi biar kita teh lebih hati-hati gitu. Tentang ada perampokan, pencurian. Ada juga tentang masalah artis. Artis yang kena tipu. Pokoknya artis yang bermasalah." - (Wawancara Samsiah, 6 April 2019). 
"Kalau di Pagi Pagi Pasti Happy itu memang enak acaranya. Ya apa namanya ya, ditampilkan sesuai, memang itu fakta. Makanya wawak seneng nonton Pagi Pagi Pasti Happy karna semua yang ditayangin itu fakta. Contohnya, ada perampokan. Gak melulu tentang artis. Ya kejanggalan gitu lah semua yang ada di luar (masyarakat umum), makanya acaranya enak ditonton" - (Wawancara Rosana, 20 April 2019).

Serta wawancara dengan praktisi Televisi, presenter berita di iNews TV, Syafinaz Nachtiar.

"Pernah. Kalau informasi apa aja, mungkin aku gak tau terlalu detail. Tapi aku pernah nonton Pagi Pagi Pasti Happy itu waktu episodenya Lucinta sama siapa tuh yang bencong juga. Terus aku juga pernah nonton yang Shafa Harris sama mamanya. Terus apa lagi ya, pokoknya semua yang rame-rame tuh aku nontonnya dari situ. Informasinya tentang apa aja pasti kan dia cuma ngulik tentang, sebenernya intinya adalah lo kenapa? Masalah itu kenapa? Kemudian di kaitkaitin sama gosip yang lain dari lambe turah. Nanti di konfirmasi apa segala macem. Paling lebih ke kayak gitu sih" - (Wawancara Syafinaz, 11 Mei 2019)

Pagi Pagi Pasti Happy mengulas secara mendalam melalui wawancara dengan bintang tamu dan dengan penayangan video video yang terkait dengan kasus yang sedang berlangsung. Dari penelitian ini dapat dilihat bahwa dalam tahap analisis stimulasi, manusia mulai menilai dan memutuskan persepsinya akan suatu hal. Pada tahap ini, tahapan seleksi persepsi hanya masuk melalui panca indra. Seleksi identik dengan kesan awal yang diterima oleh masyarakat mengenai suatu hal. Belum turut dipengaruhi oleh nilai nilai dari dalam diri maupun kepercayaan seseorang.

\section{Organisasi}

Di dalam tahap ini, proses pembentukan persepsi sudah memasuki tahapan yang berkaitan dengan faktor internal. Menurut Toha (2003) faktor internal yang mempengaruhi persepsi adalah perasaan, sikap dan karakteristik individu, prasangka, keinginan atau harapan, perhatian (fokus), proses belajar, keadaan fisik, gangguan kejiwaan, nilai dan kebutuhan juga minat, dan motivasi (Arifin, 2017, p.92). Pada tahap organisasi, para narasumber mengemukakakan tentang reaksi seputar tayangan Pagi Pagi Pasti Happy.

Berikut pernyataan narasumber terkait tahap organisasipersepsi.

"Ya kadang bagus, kadang ya nyebelin. Gitu aja campur-campur." (Wawancara Samsiah, 4 April 2019)

"Udah bener, sudah baik. Pembahasannya fakta, terus yang bawain si Uya enak. Nyata terjadi. Hostnya juga enak, kalau Uya kan memang sudah host terbaik, berpengalaman." (Wawancara Wulan, 20 April 2019)

"Enggak enggak, gak nyeleneh. Kalau itu memang fakta. Bukan dia lagi gimmick." (Wawancara Rosana, 20 April 2019)

"Bertentangan dengan nilai dalam diri, karna pertama emang dari pertanyaan yang diajuin aja memang memancing untuk bertengkar. Pertanyaannya seringkali memancing emosi gituloh. Dia gak mengkorfirmasi dengan niatan yang betul-betuk ingin konfirmasi. Tapi niatnya tuh lebih kayak mau nge-julid-in beneran gosip itu. 
Jadi kalo dibilang aku julid apa engga, ya aku juga pernah ngomongin orang. Cuma maksudnya kan kita tau etika. Ketika di TV, TV itu media yang harus bisa memberikan informasi yang benar, akurat kepada penontonnya. Jangan lagi dia bikin gosip lagi gitu loh. Udah ada gosip yang nyebar di masyarakat, di TV seharusnya diluruskan, tapi malah di TV itu juga yang menimbulkan gosip. Harusnya jangan kayak gitu, gituloh.” (Wawancara Syafinaz, 11 Mei 2019)

Pada tahap ini deitemukan bahwa narasumber memiliki ketidak samaan prinsip dengan tayangan Pagi Pagi Pasti Happy. Pasalnya narasumber menunjukan bahwa tayangan terkadang bersifat menyebalkan ditinjau dari cara berbicara host yang terkesan cerewet. Selain itu host dianggap sering melontarkan pertanyaan maupun pernyataan yang dinilai mengesampingkan nilai etika. Kerap kali narasumber merasa bahwa Pagi Pagi Pasti Happy menyiarkan informasi yang kurang akurat karena sering melebih lebihkan suatu konflik. Hal yang sering dilebih lebihkan tercermin dari sesi pembacaan micro expression hingga teknik hipnotis yang memicu munculnya rumor baru. Namun pada sisi lainnya narasumber sudah merasa memiliki ikatan tertentu dengan host Uya Kuya sehingga tidak terdapat asumsi negatif mengenai host. Selain itu narasumber juga mempercayai seluruh informasi yang disampaikan host Uya Kuya merupakan fakta dan terjadi secara nyata tanpa adanya gimmick.

\section{Interpretasi-Evaluasi}

Tahap ini berhubungan erat dengan tahapan awal yang berkaitan dengan kepercayaan serta keakuratan informasi yang ditayangkan oleh Pagi
Pagi Pasti Happy. Berikut pernyataan narasumber terkait tahapan Interpretasi-Evaluasi persepsi

"tentang buat kita teh lebih hati-hati gitu. Ada bagusnya sih. Jadi kita teh tau, oh iya (lebih waspada). Kalau ada kan dulu tentang tukang tahu diundang ya, yang tukang tahu tapi (jualannya) pakai jas, keliling gitu ya, tukang tahu pemuda, gak malu cuma sekedar jualan tahu. Pekerja keras. Itu yang gitu bagus tuh jadi ngasih inspirasi gitu." (Wawancara Samsiah, 4 April 2019)

"Ya kadang memenuhi (kebutuhan informasi) juga. Contohnya kasih tau video-video yang kita belum tau. Di nampak-in. Yang gak memenuhi itu ya misalnya dari artis artis gak semua mereka kasih tau (pengupasan informasi kurang). Tapi gak jarang juga masalah artis di kelar-in di acara itu.” (Wawancara Wulan, 20 April 2019)

"Ya iyalah, memenuhi kebutuhan informasi. Biar wawak lebih sadar sama keselamatan diri." (Wawancara Rosana, 20 April 2019)

"Kalau dibilang memenuhi informasi, enggak. Tapi ya 50:50 sih. Karena aku kerjanya di berita, jadi kan aku harus tau. Informasi kan gak cuma di berita doang. Tapi aku juga harus tau gosip dan segala macem, jadi kalau memang sekedar ingin tau gosip ya aku bisa nonton acara yang seperti itu. Tapi yang lagi 'in' aja. Sisanya aku gak pernah ngikutin sih.” (Wawancara Syafinaz, 11 Mei 2019)

Terdapat narasumber yang tidak sepenuhnya mempercayai informasi dalam tayangan Pagi Pagi Pasti Happy. Narasumber meyakini bahwa terdapat hal yang dilebih lebihkan di dalam program acara tersebut. Narasumber merupakan seorang praktisi di bidang media televisi dan ia percaya bahwa masih terdapat setting-an di dalamnya. Hal ini 
selaras dengan teori yang disampaikan oleh Adler dan Rodman (1991 p.35) dalam Desvianto, dimana faktor personal yang mempengaruhi penilaian seseorang ke dalam lima hal: pengalaman terdahulu, asumsi mengenai perilaku seseorang, ekspektasi (apakah mendukung ekspektasi mereka atau tidak), pengetahuan yang dimiliki, dan perasaan orang tersebut (Desvianto, 2013 p.107).

\section{Memori}

Pada tahap memori, narasumber akan memaparkan seputar hal yang sangat melekat tentang tayangan Pagi Pagi Pasti Happy. Tujuan pemaparan ini adalah untuk melihat penyimpanan informasi yang paling dominan di ingat oleh penonton. Samsiah narasumber pertama merespon hal yang paling diingat adalah topik ke hati hatian yang kerap ditayangkan oleh Pagi Pagi Pasti Happy. Berikut merupakan pernhataan narasumber seputar tahapan Memori persepsi.

"Iya itu kayak yang tadi itu. Tentang yang hatihati itu." (Wawancara Samsiah, 4 April 2019)

"Ya acaranya aja, ga terlalu mengungkapkan gosip gosip melulu gitu. Topiknya ganti ganti. Kadang begini kadang begitu. Kalo di TV (channel) lain gak ada, di Uya suka ditampilin ada." (Wawancara Wulan, 20 April 2019)

"Ya banyak sebenernya ya. Yang paling inget itu hostnya heboh" (Wawancara Rosana, 20 April 2019)

"Hm apa yaa, julid sih mungkin. Di trans TV kan gak cuma Pagi Pagi Pasti Happy, tapi ada juga acaranya Jedar dan Nia Ramadhani yang sama julidnya, terus udah gitu ada acara brownis yang gitu juga. Jadi apa ya, iya rumpi banget sih, infortaiment abis. Kalau yang paling melekat sih itu aja sih." (Wawancara Syafinaz, 11 Mei 2019)

Dalam wawancara yang dilakukan, tidak terdapat persamaan memori pada masing masing individu. Memori narasumber cenderung beragam. Dimulai dari memori akan kewaspadaan akan keselamatan diri, host yang membuat suasana lebih hidup, hingga tayangan yang identik dengan gosip.

5. Mengingat Kembali (Recall)

Dalam analisis recall atau mengingat kembali, narasumber akan menjabarkan seputar hal apa yang tersebesit bila mengingat Pagi Pagi Pasti Happy. Tujuan pemaparan ini adalah untuk melihat informasi apa yang paling dominan melekat di benak narasumber seputar tayangan tersebut. Top of Mind merupakan kata yang mewakili pernyataan analisis recall ini. Berikut merupakan pernyataan narasumber seputar tahapan Recall persepsi.

"Hostnya. Uya Kuya kalau bawa acara heboh, ceria bawaanya." (Wawancara Samsiah, 4 April 2019)

"Uya Kuya. Kalau Pagi Pagi Pasti Happy itu ya Uya Kuya terutama.” (Wawancara Rosana, 20 April 2019)

"Ya langsung keingetnya sih karena sering ngeliatin video video viralnya itu. Yang kadang di TV gak ada, di dia ada. Acaranya ga terlalu mengungkapkan gosip gosip melulu gitu." (Wawancara Wulan, 20 April 2019)

"Uya Kuya. Iya, tapi kalau tadi kamu nanya pas pertama kali, aku tau Pagi Pagi Pasti Happy nggak, aku jawab Nikita Mirzani kan. Karna memang dia juga sama top of mind nya kan dua duanya kan. Ya gitu lah menurut aku, gak ada yang bikin aku inget banget tentang Pagi Pagi Pasti 
Happy karna aku nonton ketika ada kasus yang 'in’ doang. Pasti setiap episodenya ada kan dia. Nah aku gak nonton. Aku hanya nonton kayak yang Lucinta Luna kemaren. Shafa Harris kemaren. Sisanya udah aku gak tau lagi. Dia nayangin apa aja aku gak tau." (Wawancara Syafinaz, 20 April 2019)

Dari hasil wawancara yang dilakukan dengan narasumber, proses mengingat kembali identik dengan hal yang paling melekat di ingatan tentang suatu hal. Uniknya, dominan narasumber mengungkapkan bahwa dalam proses recall mereka mengingat uya kuya yang merupakan presenter tayangan Pagi Pagi Pasti Happy.

\section{SIMPULAN}

Dari penelitian yang telah dilakukan mengenai persepsi masyarakat terhadap Pagi Pagi Pasti Happy: Studi Pada Masyarakat di Kota Bogor, didapatkan hasil dari dua tujuan penelitian yang ingin diteliti. Tujuan utama ialah untuk mengetahui mendeskripsikan persepsi masyarakat di Kota Bogor terhadap tayangan Pagi Pagi Pasti Happy di Trans TV. Persepsi masyarakat di Kota Bogor terhadap tayangan Pagi Pagi Pasti Happy dinilai baik karena tiga responden merasa kebutuhan informasi pribadi dapat terpenuhi melalui tayangan Pagi Pagi Pasti Happy. Sedangkan salah satu responden merasa kebutuhan informasi pribadi tidak terpenuhi oleh tayangan tersebut.

Seluruh narasumber percaya akan keakuratan informasi yang disampaikan oleh Pagi Pagi Pasti Happy. Namun salah satu narasumber berkomentar bahwa seringkali tayangan seolah olah di besar besarkan sehingga memancing perhatian penonton.
Salah satu contohnya ialah pemanggilan ahli yang dapat membaca mimik wajah serta teknik hipnotis.

Ditinjau dari tujuan kedua yaitu untuk mengetahui bagaimana persepsi positif dan negatif masyarakat di Kota Bogor terhadap tayangan Pagi Pagi Pasti Happy, diketahui bahwa persepsi masyarakat cukup beragam namun cenderung positif. Narasumber memiliki persepsi positif ditinjau dari fase kedua yaitu organisasi. Didalam analisis organisasi yang terbagi menjadi aturan, skema dan naskah, narasumber menilai tidak terdapat hal hal yang kontradiktif ditinjau dari prinsip dalam diri. Selain fase organisasi, refleksi persepsi positif terlihat ketika dilakukan wawancara tentang informasi apa yang terdapat dalam tayangan Pagi Pagi Pasti Happy, informan mengungkapkan topik bernuansa positif yang ditayangkan program acara tersebut. Serta dalam fase selanjutnya yaitu interpretasi - evaluasi, narasumber mempercayai keakuratan informasi dalam tayangan Pagi Pagi Pasti Happy.

Hal positif lainnya ditinjau dari respon narasumber yang merasa kebutuhan informasinya terpenuhi khususnya pada informasi seputar konflik public figure, human interest serta penayangan video viral yang dianggap menghibur. Menurut narasumber, Pagi Pagi Pasti Happy menayangkan fakta tanpa adanya gimmick tertentu. Tayangan tersebut dinilai kerap menginspirasi apabila mengulas hal hal yang bertema human interest serta dinilai baik karena kerap mengulas secara dalam dan tajam seputar konflik public figure. Menurut narasumber, tak jarang Pagi Pagi Pasti Happy menyelesaikan konflik antar dua kubu dengan mendatangkan keduanya di saat yang bersamaan. 
Persepsi negatif juga berkembang dalam masyarakat mengenai tayangan Pagi Pagi Pasti Happy. Tayangan tersebut dianggap mengenyampingkan etika penyiaran, dimana tayangan televisi sebaiknya mendidik serta menyiarkan informasi yang akurat. Pagi Pagi Pasti Happy dianggap informatif namun tetap terdapat unsur yang terkesan melebih-lebihkan masalah. Hal ini tercermin dari teknik pembacaan micro expression serta hipnotis yang ada di dalam tayangan tersebut. Selain itu, host dinilai cerewet dan kerap melontarkan kata-kata yang memicu konflik baru baik antar bintang tamu maupun penonton.

\section{DAFTAR PUSTAKA}

Anasthasya, M. (2018, September 19). BPS Kota Bogor Ekspos Data: Angka Kemiskinan Turun, IPM Naik. Diperoleh Oktober 18, 2018, dari Radarbogor.id:

http://www.radarbogor.id/2018/09/19/bps-kotabogor-ekspos-data-angka-kemiskinan-turun-ipm$\underline{\text { naik/ }}$

Arifin, H.S., Fuady, I., \& Kuswarno, E. (2017). Jurnal Penelitian Komunikasi dan Opini Publik. Analisis Faktor yang Mempengaruhi Persepsi Mahasiswa Untirta Terhadap Keberadaan Perda Syariah di Kota Serang., 21(1), 89-92. Diperoleh dari: http://ejournal.upbatam.ac.id/index.php/commed/a rticle/view/157

Asngad, M. (2016). Persepsi Mahasiswa Terhadap Peringatan Bahaya Merokok Pada Setiap Kemasan Rokok. Institut Agama Islam Negeri, Fakultas Dakwah. Purwokerto: repository.iainpurwokerto.ac.id.

Aurelia, A. W. (2018, April 16). Kemasan Acara Hiburan TV Indonesia: Semakin Alay Semakin Digemari. (F. Salam, Editor) Diperoleh Oktober 18, 2018, dari Tirto.id:https://tirto.id/kemasanacara-hiburan-tv-indonesia-semakin-alaysemakin-digemari-cHvD

Badan statistik kabupaten tangerang. (2018, January 5). badan statistik kabupaten tangerang. Diperoleh October 18, 2018, dari tangerangkab.bps.go.id:https://tangerangkab.bps.g o.id/pressrelease/2018/01/05/6/angka-kemiskinanprovinsi-banten-september-naik-menjadi-5-59persen.html

Chaplin, J. P. (2011). Kamus Lengkap Psikologi. Jakarta: PT Raja Grafindo Persada

Desvianto, S. (2013). Jurnal E-Komunikasi. Studi Fenomenologi: Proses Pembentukan Persepsi Mantan Pasian Depresi di Rumah Pemulihan Soteria. 1(3), $107 . \quad$ Diperoleh dari:http://publication.petra.ac.id/index.php/ilmukomunikasi/article/view/925/825

DeVito, J. A. (1997). Komunikasi Antarmanusia. Profesional Books: Jakarta

DeVito, J. A. (2009). Human Communication: The Basic Course. New York: Pearson Education, Limited.

Fairush, E. D. (2013). Persepsi Aremania Terhadap Paham Ultras (Studi Deskriptif Kualitatif pada Anggota Komunitas GATE 4 Suporter Arema Indonesia). Universitas Brawijaya, Fakultas Ilmu Sosial dan Ilmu Politik. Malang: academia.edu.

McQuail, D. (2011) Teori Komunikasi Massa. Jakarta: Salemba Humanika

Nielsen Consumer Media View (CMV). (2017, July 27). Penetrasi Media Televisi Masih yang Tertinggi. Diperoleh Oktober 16, 2018, dari katadata:https://databoks.katadata.co.id/datapublis h/2017/07/27/penetrasi-televisi-masih-yangtertinggi

Nurfikria. I., dan Tawulo, M. A. (2018). Jurnal Riset Komunikasi. Komodikasi Konflik Dalam Tayangan Televisi (Kajian terhadap Program Acara Pagi-Pagi Pasti Happy di Trans TV). 1(1), $55 . \quad$ Diperoleh dari: https://jurnalrisetkomunikasi.org/index.php/jrk/art icle/view/13/7

Panuju, R. (2017). Sistem Penyiaran Indonesia. Jakarta: KENCANA.

Rosihan, A. (2012). Stereotipisasi Etnis Pribumi Atas Etnis Pendatang (Disertasi Skripsi, Universitas Indonesia, Jakarta). Diperoleh dari: http://lib.ui.ac.id/file?file=digital/20307922T\%2031402-Stereotipisasi\%20etnisfull\%20text.pdf

Staubhaar, J., LaRose, R., Davenport, L. (2012). Media Now (Understanding Media, Culture and Technology). Boston: Michael Rosenberg. 
Yulianti, S. (2013). eJournal Ilmu Komunikasi. Persepsi Masyarakat Tentang Program Acara Reality Show "Catatan Si Olga" di Kelurahan Gunung Lingai Kecamatan Sungai Pinang Samarinda. 1(1), 47-48. Diperoleh dari:http://ejournal.ilkom.fisipunmul.ac.id/site/wp content/uploads/2013/02/01_format_artikel_ejour nal_mulai_hlm_ganji1\%20(02-27-13-12-50-

12).pdf 